\title{
IMPACT OF BIO AND ORGANIC SOIL AMENDMENTS ON SUNFLOWER DAMPING-OFF AND ROOT-ROT DISEASES UNDER RECLAIMED SOIL
}

\author{
Abeer E. El-Hadidy \\ Department of Plant Protection, Desert Research Center, El-Matareya, \\ Cairo, Egypt \\ E-mail: elhadidyabeer@gmail.com
}

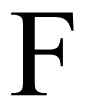

ield experiment was carried out at El-Nubaria Province, El-

Behaira Governorate to investigate the effect of some organic and biofertilization treatments as soil amendments on suppression Macrophomina phasolina, Sclerotium rolfisii, and Rhizoctonia solani, the causal pathogens of root-rot and damping-off of sunflower (Helianthus annuus L.). Organic amendment treatments increased the sunflower resistance to soil borne diseases hence enhanced its productivity. The most promising results obtained from rice straw+EM1+Urea, biochar+compost, rice straw+EM1 and EM-Bokashi with no significant differences, compost and animal manure, respectively compared to the control treatment (without organic amendment). EM-X (EM1+Bacillus subtilis + mycorrhiza + Azotobacter sp.) was found to be more effective in reducing $M$. phaseolina, $S$. rolfisii, and $R$. solani population and root-rot incidence, therefore enhance sunflower productivity compared to the other examined biofertilization treatments including the conventional chemical fertilization as the control treatment. The integration between rice straw+EM1+Urea or biochar+compost and EM-X was found to be the furthermost advised agricultural practices for soil borne diseases management as land degradation neutrality (LDN) technology that enhances land cover and area unit productivity under these conditions.

Keywords: sunflower, soil amendments, Macrophomina phasolina, Sclerotium rolfisii, Rhizoctonia solani

Sunflower (Helianthus annuus L.) is an oil seed species that is characterized by high productivity with high quality oil under a wide range of environmental stresses during its growing season (Weiss, 2000). Soilborne diseases are a major threat to sunflower production in Egypt and worldwide for the wide host range of the pathogens, which survive long time in the soil (Abd El Hai et al., 2009). Chemical control was massively applied, however, for the increasing public concern over the fungicide usage, 
alternative control methods are strongly desired for sustainable agriculture, where organic amendments play an important role (Mehta et al., 2014). Biological control is one of the viable, ecofriendly propositions, which can substantially minimize the disease. Several biocontrol agents (BCAs) were reported to be effective in the bio-suppression of root-rot pathogens on various crops. Among the group of BCAs, plant growth promoting rhizobacteria (PGPR) have been widely used for the bio-suppression of various soil-borne diseases (Deshmukh et al., 2016). They have tremendous ability to be used as biocontrol agents particularly as biofertilizers because of their significant impact on the plant health, suppression of disease-causing microbes and ability to facilitate nutrient assimilation (Bouizgarne, 2013). The use of beneficial and effective microorganisms (EM1) as microbial inoculants in agriculture is a promising new technology. It has been shown to be effective in improving soil health and quality, inevitably raising the yield and quality of crops. Employing EM composting fertilizer and EMactivated liquid has been shown to promote root growth and improve the germination potential and germination rate. EM1 is a mixed culture of beneficial and naturally occurring microorganisms, such as species of photosynthetic bacteria (Rhodopseudomonas palustris and Rhodobacter sphaeroides), lactobacillus (Lactobacillus plantarum, L. casei and Streptococcus lactis), yeasts (Saccharomyces spp.), and Actinomycetes (Streptomyces spp.) While EM5 is a modification product from EM1 that created by adding vinegar and ethyl alcohol during the fermentation process in order to have multifunction product; such as foliar fertilizer and insect repellent (Higa, 2000). Using EM improves crop growth and yield by increasing photosynthesis, producing bioactive substances; such as hormones and enzymes, controlling soil diseases and accelerating decomposition of lignin materials in the soil and generally improves soil physical and chemical properties and favors the growth and efficiency of symbiotic microorganisms; such as nitrogen fixing rhizobia and arbuscular mycorrhizal (AM) fungi (Sharma et al., 2014 and Figueiredoet al., 2016).

The use of organic amendments; such as animal manure, green manure, composts and peats is one of the successful control methods of soil borne diseases. The addition of organic matter in soil provide disease control through variety of mechanism; such as providing antimicrobial compounds during decomposition (Mehta et al., 2014) reduced the inoculum density of the soil borne plant pathogens through changes in the general microbial balance by different mechanism (Kausar et al., 2016). Similarly, biochar, which is a carbon rich soil amendment that is produced as a byproduct during the pyrolysis of the agriculture wastes to produce the thermal gas, can significantly improve the gravimetric moisture content of soil, increase soil $\mathrm{pH}$ significantly. Also, biochar addition to soil alters microbial populations in the rhizosphere, albeit via mechanisms not yet understood, and may cause a shift towards beneficial microorganism populations that promote plant

Egyptian J. Desert Res., 68, No. 2, 277-298 (2018) 
growth and resistance to biotic stresses. There are also some scant evidences for biochar-induced plant protection against soil borne-diseases, the induction of systemic resistance towards several plant pathogens in different crop systems (Bonanomi et al., 2015).

EM was supplied as microbial stock suspension and fermented organic matter (EM-bokashi). EM-bokashi is a Japanese expiration that points to an effective organic fertilizer in nature farming crop production (Higa, 2000). EM-bokashi, compost and animal dung stimulated plant resistance to soil-borne diseases, therefore enhanced significantly plant growth, yield and its attributes and chemical composition (Abdel-Ati and ElHadidy, 2013 and Shin et al., 2017).

This work aimed to study the effect of different soil amendments as an effective ecofriendly strategy to manage damping-off and root-rot diseases that challenge sun flower productivity under the Egyptian reclaimed soil conditions.

\section{MATERIALS AND METHODS}

\section{Isolation of Associated Fungi Causing Damping-off and Root-rot of Sunflower}

During 2016 growing season, sunflower field with recent history of severe damping off and root-rot diseases was monitored at Nubaria area. Diseased sunflower plants were collected 15, 45 and 90 days after sowing, the causal pathogens were conducted isolated on Potato Dextrose Agar medium (PDA). The identification of isolated fungi was carried out according to Gilman (1971) and Barnett and Hunter (1987).

\section{Pathogenicity Test of Isolated Fungi}

The experiment was carried out in artificiality infested sandy clay soil at the greenhouse of Plant Protection Department, Desert Research Center (DRC). Inocula of isolated fungi, i.e. Macrophomina phasolina, Sclerotium rolfisii, Rhizoctonia solani and Fusarium solani were prepared with $5 \mathrm{~g} / \mathrm{kg}$ soil of barley grain inoculum and incorporated to soil. Seeds of sunflower var. Giza 102 were surface disinfested with $2 \%$ sodium hypochlorite, rinsed in sterile distilled water, and sown in $25-\mathrm{cm}$ plastic pots filled with autoclaved clay and sand $(1: 1, \mathrm{v} / \mathrm{v})$. Four replicates of each isolate were prepared; five seeds of sunflower were sawn in each pot. Plants were watered as needed and treated according to the normal agricultural practices. Re-isolation was conducted to insure the association of the tested isolates with the developed diseases. The incidence of pre and post emergence damping off, root-rot diseases and survived plants were calculated at 15, 30 and 45 days after planting, respectively. 


\section{Field Experiment}

The experiment was carried out at El-Nubaria Province, the desert backyard of El-Behaira Governorate, Egypt (field with history of severe infection with sunflower damping-off and root- rot diseases), during two successive seasons of 2015 and 2016, to investigate the effect of some commercial biofertilizer treatments and different organic soil amendments on damping-off and root-rot diseases of sunflower var. Giza-102. Physical and chemical analysis of the experimental soil was determined and included the following characters: sand $91.20 \%$, silt $3.70 \%$, clay $5.10 \%$, pH 7.80 , organic matter $0.21 \%$. $\mathrm{Ca} \mathrm{CO}_{3} 1.00 \%$, E.C. $0.50 \mathrm{mmhos} / \mathrm{cm}^{3}$. The available total $\mathrm{N}, \mathrm{P}, \mathrm{K}$ were $8.10,3.20,20.0 \mathrm{ppm}$, respectively at $0-60 \mathrm{~cm}$ depth as described by Chapman and Pratt (1978). The experimental soil was ploughed twice, ridged and divided into plots 4 meters long and 3.60 meter apart including 6 ridges with 0.60 and $0.20 \mathrm{~cm}$ apart between rows and hills, respectively, and the total plot area was $14.4 \mathrm{~m}^{2}$. During soil preparation, $150 \mathrm{~kg}$ calcium super phosphate/fed $\left(15.5 \% \mathrm{P}_{2} \mathrm{O}_{5}\right)$ was added as a general application, while $45 \mathrm{~kg} \mathrm{~N} / \mathrm{fed}$ as ammonium sulphate $(20.6 \% \mathrm{~N})$ was added in three equal doses at sowing, after thinning and pre-configured buds flowering, whereas $50 \mathrm{~kg} /$ fed potassium sulphate $\left(48 \% \mathrm{~K}_{2} \mathrm{O}\right)$ was added after plant thinning.

Seeds of sunflower var. Giza-102 were obtained from Agricultural Research Center, Giza, Egypt, were sown at 15 March in both seasons at seeding rates of $5 \mathrm{~kg} /$ fed (3-5 seeds per hill) and thinned at 15 days after sowing date.

The organic amendment treatments were added into each plot in the rate of $20 \mathrm{~m}^{3} / \mathrm{fed}$ and mixed with the soil before planting. It consisted of five treatments as follows; without treatment (control), rice straw (after fermentation with EM1 and water for two months) (in order to adjust the $\mathrm{C} / \mathrm{N}$ ratio), biochar of rice straw $(2 \% \mathrm{w} / \mathrm{w})$ and compost (in order to adjust the $\mathrm{C} / \mathrm{N}$ ratio), EM-bokashi and animal manure. The used compost in the experiment was town refuse compost.

The biofertilizer treatments were added with irrigation water. It consisted of four treatments as follows; without treatment (control), EM1 (4 L/fed with irrigation water $0.4 \%$ ), EM5 (4 L/fed with irrigation water $0.4 \%$ ) and EM-X (EM1+Bacillus subtilus + Azotobacter chrococcum + arbuscular mycorrhiza 4 L/fed with irrigation water $0.4 \%$ ) according to Abdel-Ati and El-Hadidy (2017). The experimental design that used in this experiment was strip plot design in four replicates, where the organic amendment treatments were the first strip, the biofertilizers treatments were arranged in the second strip. The effective microorganisms (EM1) contains selected species of microorganisms including predominant populations of lactic acid bacteria and yeasts, and smaller numbers of photosynthetic bacteria, actinomycetes and other types of organisms such as mycorrhizae. Consequently, EM5 is a modification product from EM1 that created by adding vinegar and ethyl

Egyptian J. Desert Res., 68, No. 2, 277-298 (2018) 
alcohol during the fermentation process in order to have multifunction product; such as foliar fertilizer and insect repellent (Higa, 2000). Later on, the new modification of EM-X was made by Abdel-Ati and El-Hadidy (2015) as a new formula for EM1 through different experiments for series of $B$. subtilus $+A$. chrococcum + arbuscular mycorrhiza, which were fermented in the classical EM1 for 45 days before usage. The EM1 was kindly obtained from EM project-EEAA-Ministry state of Environmental Affairs, while the liquid culture of B. subtilus, A. chrococcum and arbuscular mycorrhiza were kindly obtained from microbial research center (Cairo- MIRCEN), the unite biofertilizers, Faculty of Agriculture, Ain Shames University. The Biofertilizers application scheme was applied three times in equal doses.

\section{Data Recorded}

\subsection{Disease incidence}

Percentage of pre and post damping-off as well as root-rot incidence were recorded at 15, 45 and 90 days after sowing date, and then expressed as a percent of infected plants.

\subsection{Population of the fungal pathogens in plant rhizosphere}

Soil samples were collected from each plot at $0,15,45$ and 90 days after sowing. Samples were taken from plant rhizosphere, $15 \mathrm{~cm}$ of the soil surface, where four soil extracts were prepared for each plot. Serial dilutions of $10 \mathrm{~g}$ soil $/ 90 \mathrm{ml}$ of sterile distilled water were made to obtain $10^{3}$ dilution and $0.1 \mathrm{ml}$ of each dilution was spread plated on appropriate selective media (Ko and Hora, 1971; Cloud and Rupe, 1991 and Steadman et al., 1994) for enumeration of the most expected pathogenic fungi. Inoculated plates were incubated at $25^{\circ} \mathrm{C}$ in darkness and developed colonies were enumerated five days after inoculation.

\subsection{Microbial population in plant rhizosphere}

Soil extracts were prepared and $10^{3}$ dilutions were made as above mentioned. A $0.1 \mathrm{ml}$ of each dilution was spread plated on each of Lingappa and Lockwood (1962) and Collins and Lyne (1985) media for the total counting of actinomycetes and bacteria, respectively. Plates were incubated at $30^{\circ} \mathrm{C}$ in darkness for three days before counting bacterial colonies and for five days before counting actinomycetes.

\subsection{Plant growth and yield assessment}

At harvest, a random sample of ten plants were taken from each plot to determine following; plant height $(\mathrm{cm})$, oil yield (ton/fed), which was estimated by ground dry mature seeds into very fine powder to determine oil percentage using Soxhlet apparatus and diethylether according to A.O.A.C. (1990), then the oil yield was estimated by multiplying seed oil percentage by seed yield (ton/fed). 


\section{Statistical Analysis}

Pooled data were subjected to the combined statistical analysis after passing the homogeneity test using M-STAT C (Russell, 1991), while Duncan's multiple range test was used to verify the significant differences between treatments means as described by Duncan (1955).

\section{RESULTS AND DISCUSSION}

\section{Pathogenicity Test of Isolated Fungi the Causal of Damping off and Root-rot Diseases}

As shown in table (1), the fungi isolated and identified in the samples of the infested sunflower showed clear symptoms of root-rot, therefore pathogenicity of the recovered fungi revealed that Macrophomina phasolinae, Sclerotium rolfsii and Rhizoctonia solani were the most virulent pathogens of pre-emergence damping-off stage assessed 15 days after sowing. These fungi recorded $34.3,32.5$ and $27.5 \%$, respectively, however, Fusarium solani was the lowest in pathogenicity (18.9\%). At the post emergence damping-off stage, 30 days from sowing, $R$. solani, S. rolfsii and $M$. phasolinae fungi incited more disease being $29.3,27.5$ and $26.6 \%$, respectively. Moreover, F. solani incited $17.8 \%$ damping-off. However, at 45 days after sowing, $R$. solani, S. rolfsii, M. phaseolina and $F$. solani showed 35.2, 34.6, 33.5 and $26.3 \%$, respectively, as root-rot disease. These observations agree with several reports in Egypt and other parts of the world (Morsy and El-Korany, 2007 and Abd El-Hai et al., 2009).

Table (1). Pathogenicity test of the isolated fungi in a pot experiment.

\begin{tabular}{lccc}
\hline \multirow{2}{*}{ Isolated Fungi } & \multicolumn{2}{c}{ Damping-off (\%) } & Root- rot \\
\cline { 2 - 3 } & $\begin{array}{c}\text { Pre-emergence } \\
\text { damping off }\end{array}$ & $\begin{array}{c}\text { Post- emergence } \\
\text { damping off }\end{array}$ & $\begin{array}{c}\text { (\%) } \\
\text { Macrophomina phasolinae }\end{array}$ \\
Rhizoctonia solani & $27.3 \mathrm{a}$ & $26.6 \mathrm{a}$ & $33.5 \mathrm{a}$ \\
Sclerotium rolfsii & $32.5 \mathrm{~b}$ & $29.3 \mathrm{a}$ & $35.2 \mathrm{a}$ \\
Fusarium solani & $18.9 \mathrm{c}$ & $27.5 \mathrm{a}$ & $34.6 \mathrm{a}$ \\
Control & $0.0 \mathrm{~d}$ & $17.8 \mathrm{~b}$ & $26.3 \mathrm{~b}$ \\
\hline
\end{tabular}

Means having similar letters at same column has no significant differences at $P \geq 0.05$

\section{Effect of Organic Amendments on}

2.1 Damping off and root-rot diseases

Results illustrated in fig. (1) indicate that the most effective treatment for suppressing damping off and root-rot incidence was rice straw+EM1+Urea, followed by biotchar+compost, then rice straw+EM1 and then EM-bokashi. While the compost, cow manure and control treatments exhibited the lowest effect, respectively. This agrees with what reported by Bonanomi et al. (2015), who told that the utilization of organic amendments 
has been proposed to decrease the incidence of plant diseases caused by soilborne pathogens. Rice straw as soil amendment suppresses soil borne diseases as bioenhancer and bioprotectant (Kausar et al., 2016). Application of urea to soil was effective in preventing carpogenic germination of sclerotia of S. sclertiorum, that were not in direct contact with the soil and they suggested that ammonia was the key toxic component for the suppression of this pathogen (Hung-Chang et al., 2002). Biochar as a new soil amendment can be effective against soilborne pathogens e.g. Fusarium spp., Phytophthora spp., Rhizoctonia solani (Bonanomi et al., 2015). In contrary with the EM-Bokashi, the use of the chemical fertilization under this biotic stress conditions not only affect the virgin environment and human health negatively, but it increases the probability of infection and development of root-rot pathogens as a result of plant cell elongation, rapid cell mitosis, thinness of cell walls caused by the presence of nitrogen compounds in high concentration within short time period as happened when nitrogen fertilization is applied. These conditions might be perfect for the soil borne diseases to produce its mass injury (Higa, 2000 and Abdel-Ati and El-Hadidy, 2013).

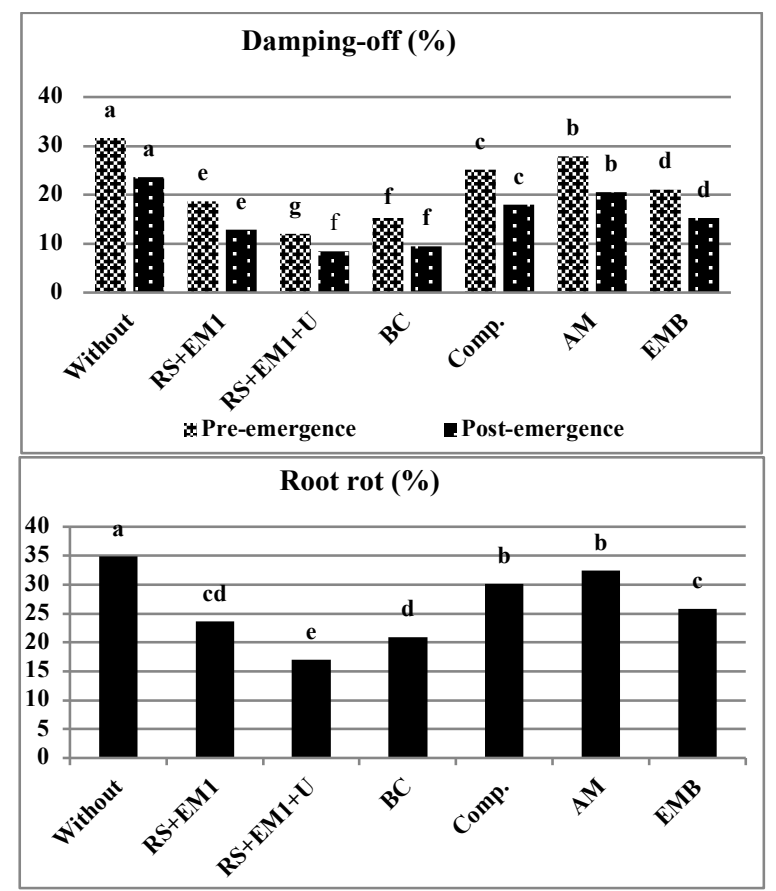

Fig. (1). Effect of different organic amendments on the incidence of damping-off and root-rot diseases of sunflower.

Means having similar letters at same column has no significant differences at $P \geq 0.05$

RS-EM ${ }_{1}=$ Rice straw $+\mathrm{EM}_{1}$, RS-EM1-U= Rice Straw+EM1+Urea, B-C= Biochar+Compost,

Comp.$=$ Compost, $\mathrm{AM}=$ Animal Manure, $\mathrm{EM}-\mathrm{B}=\mathrm{EM}-\mathrm{Bokashi}$ 


\subsection{Fungal pathogens and microbial population}

Data presented in fig. (2) indicate that all organic amendments, except cow manure decreased populations of the associated fungal pathogens significantly, i.e. M. phaseolina, S. rolfsii and $R$. solani. The most effective treatment was rice straw+EM1+urea for all fungal pathogens, followed by the biochar+compost, then rice straw+EM1 and EM-bokashi amendments. However, the cow manure did not exhibit any significant effect, similarly as reported by Abdel-Ati and El-Hadidy (2013) and Kausar et al. (2016). The decline in the inoculum potential of $M$. phaseolina by incorporation of organic amendments might be due to the release of toxicants (Reddy, 2016). Results illustrated that all soil amendments, except cow manure increased the population beneficial microbial soil; the stimulated saprophytic microbial soil population depleted the nitrogen level or changes its form in the soil resulting in impairing the infection process by the pathogen (Reddy, 2016).

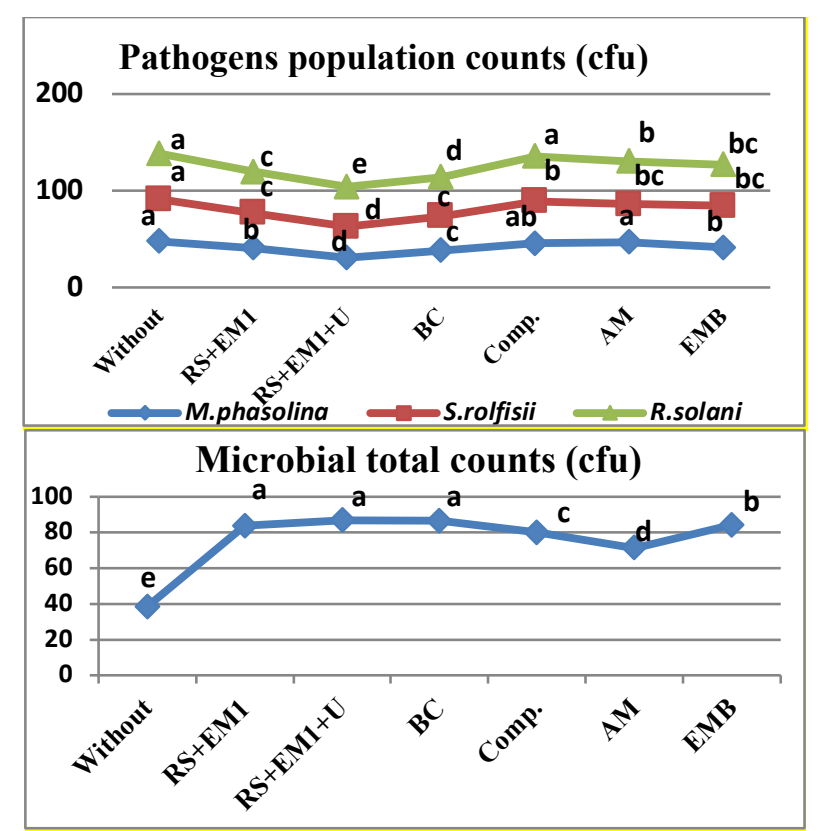

Fig. (2). Effect of different organic amendments on pathogens population and microbial total counts in sunflower rhizosphere.

Means having similar letters at same column has no significant differences at $P \geq 0.05$

$\mathrm{WT}=$ Without Treatment (control), $\mathrm{RS}-\mathrm{EM}_{1}=$ Rice straw $+\mathrm{EM}_{1}, \mathrm{RS}+\mathrm{EM} 1+\mathrm{U}=$ Rice Straw+EM1+Urea, $\mathrm{B}+\mathrm{C}=$ Biochar + Compost, Comp. $=$ Compost, $\mathrm{AM}=$ Animal Manure, EM$\mathrm{B}=$ EM-Bokashi

Egyptian J. Desert Res., 68, No. 2, 277-298 (2018) 


\subsection{Sunflower growth and yield}

Results shown in fig. (3) indicate that effect of applying the different soil amendments to the rhizosphere of sunflower var. Giza 102 grown under Nubaria province conditions and infected with root-rot and damping off diseases, increased significantly plant height $(\mathrm{cm})$, seed yield (ton/fed) and the oil yield (ton/fed), compared to the control treatment. The highest significant observations were obtained from rice straw+EM1+urea, biochar +compost, rice straw+EM1 and EM-bokashi with no significant differences, compost and animal manure, respectively, compared to the control treatment (without organic amendment). This may be due to that organic amendments improve the soil properties by improving the soil structure, enhancing plant soil water relations and fertility (Bonanomi et al., 2010). Organic manures as well contain many plant nutrients (nitrogen, phosphorus, potassium and many other essential nutrients) and it also increases infiltration of water and enhances retention of nutrients, reduces wind and water erosion, thus promoting plant growth and productivity as reported by Higa (2000).
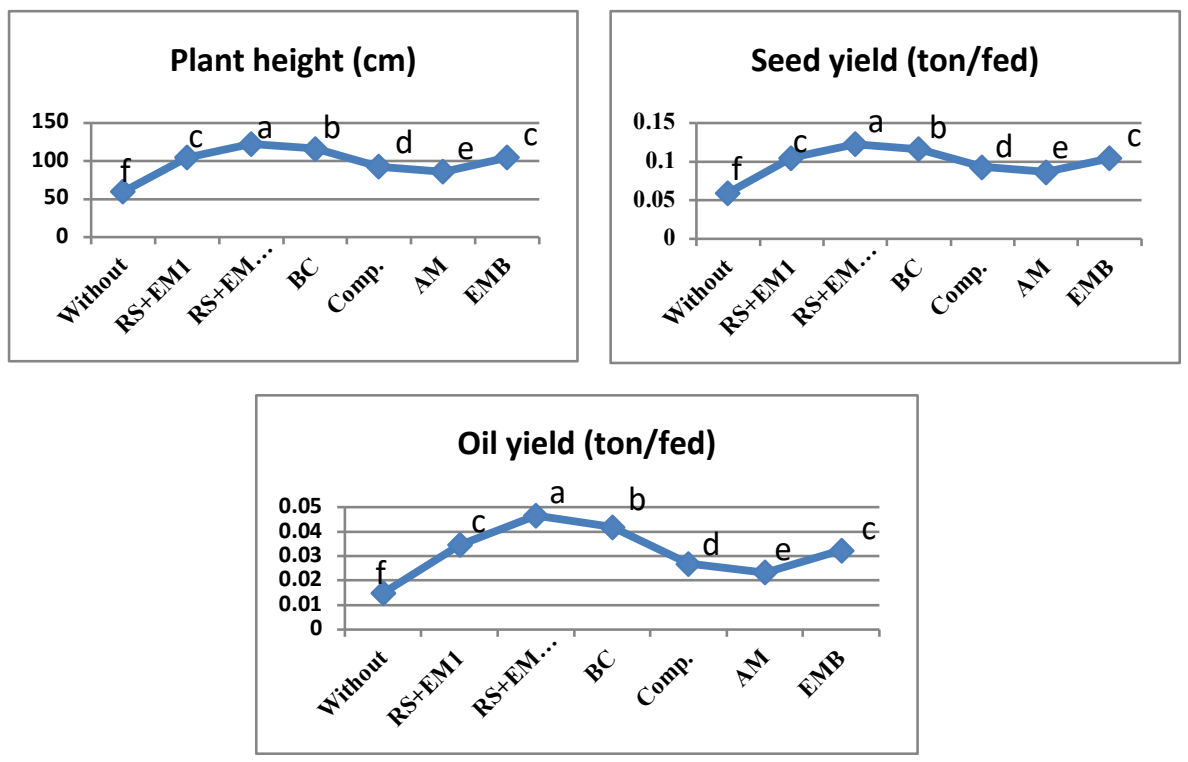

Fig. (3). Effect of different soil amendment treatments on sunflower plant height $(\mathrm{cm})$ and yield (ton/fed) under Nubaria province conditions.

Means having similar letters at same column has no significant differences at $P \geq 0.05$

$\mathrm{WT}=$ Without Treatment (control), RS-EM $\mathrm{EM}_{1}=$ Rice straw $+\mathrm{EM}_{1}$, RS-EM1-U= Rice Straw+EM1+Urea, B-C= Biochar + Compost, Comp. $=$ Compost, $\mathrm{AM}=$ Animal Manure, EM$\mathrm{B}=$ EM-Bokashi 


\section{Effect of Bio fertilization Treatments on \\ 3.1. Damping off and root-rot diseases}

Data in fig. (4) indicate that there was significant impact of biofertilization treatments; i.e. EM1, EM5 and EM-X for suppression both damping off and root-rot diseases, compared to the conventional chemical fertilization as the control treatment. EM-X treatment had the most significant effective to suppress both pre and post emergence damping-off, followed by EM5 and EM1, respectively, compared to conventional chemical fertilization as the control treatment. Meanwhile, data in fig. (4) also show that there were significant variations between the biofertilizer treatments for reducing root-rot compared with conventional as a control treatment. EM5 and EM-X treatments showed the minimum disease incidence, followed by EM1 respectively, compared to conventional as a control treatment. As EM1 consists of lactic acid bacteria, yeasts, photosynthetic bacteria, actinomycetes and other types of organisms; such as mycorrhizae, which are mutually compatible with one another and coexist in based molasses liquid culture, while EM5 exceeds with ethyl alcohol and sugar cane vinegar (Higa, 1991). So, they seemed to be more applicable under the study conditions. In addition, several substances produced by antagonistic rhizobacteria may be related to both pathogen control and promotion of plant growth and productivity, such as siderophores and antibiotics that was clear by different biofertilization application (Figueiredo et al., 2016), particularly when $\mathrm{EM} 1+B$. subtilis + mycorrhiza+Azotobacter sp. were integrated together under the name EM-X. Azotobacter plays an important role in the nitrogen cycle in nature as it possesses a variety of metabolic functions. Besides playing role in nitrogen fixation, Azotobacter has the capacity to produce vitamins; such as thiamine and riboflavin, and plant hormones viz., indole acetic acid (IAA), gibberellins (GA) and cytokinins (CK). A. chroococcum improves the plant growth by enhancing seed germination and advancing the root architecture by inhibiting pathogenic microorganisms around the root systems of crop plants (Bhardwaj et al., 2014). Soil application with Bacillus subtilis decreased the incidence of damping-off and root-rot, increased the number of survived peanut plants in M. phaseolina and/or R. solani infested soil in comparison with the control (Abd-El-Khair et al., 2016). Mechanisms involved in Bacillus sp. eliciting plant growth promotion include auxin production, increased uptake availability of phosphorus biocontrol abilities and induction of systemic resistance (Bouizgarne, 2013).

\subsection{Fungal pathogens and microbial population}

Data in fig. (5) present that the variation effectives of biofertilizers i.e. EM1, EM5 and EM-X on fungal populations; i.e. M. phaseolina, $S$. rolfsii and $R$. solani as well as soil microbial total counts compared with conventional as a control treatment. Data showed that the lowest significant population of three fungal pathogens was recorded by EM5 and EM-X, 
followed by EM1 compared with conventional as a control treatment. Meanwhile, the biofertilization treatments encouraged significantly the soil microbial total counts compared to the conventional as a control treatment. The most significant increase in total counts of both soil bacteria actinomycetes was showed by EM5, followed by EM-X while, EM1 treatments had the lowest significant effect when compared with conventional as a control treatment. According to Tokeshi et al. (1998), beneficial microorganisms (EM) were found to be suppressive to the soilborne plant pathogen Sclerotinia sclerotiorum. Control of fungal pathogens may be attributed to the activity of lactic acid bacteria in the beneficial microorganisms mixture that produce lactic acid, a strong sterilizing compound (Higa, 2000). As EM1 consists of lactic acid bacteria, yeasts, photosynthetic bacteria, actinomycetes and other types of organisms; such as mycorrhizae, which are mutually compatible with one another and coexist in based molasses liquid culture, while EM5 exceeds with ethyl alcohol and sugar cane vinegar (Higa, 1991). So, they seemed to be more applicable under the study conditions.

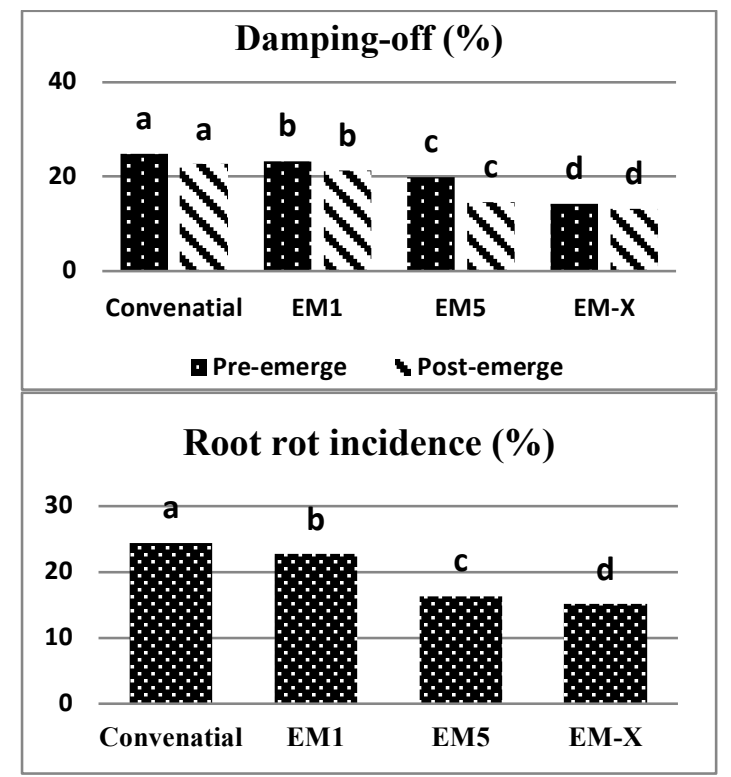

Fig. (4). Effect of biofertilizion treatments on damping off and root-rot diseases.

Means having similar letters at same column has no significant differences at $P \geq 0.05$ 


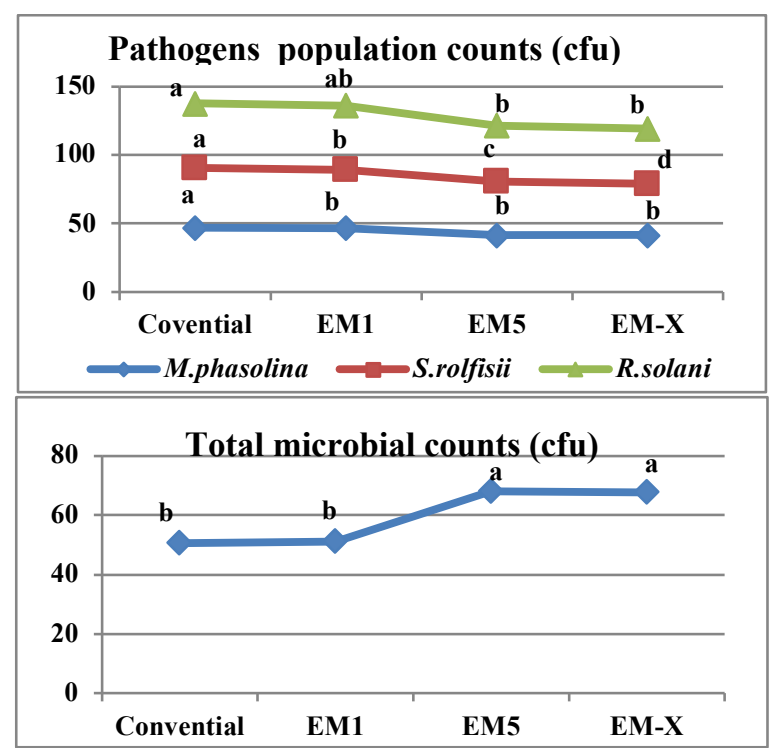

Fig. (5). Effect of biofertilizion treatments on fungal pathogens population and total microbial counts.

Means having similar letters at same column has no significant differences at $P \geq 0.05$

As the alcoholic sugars have a smaller liner shape molecule that was capable to enter the plant stomatal system easier and faster than any other molecule shape (Edwards et al., 1998), thus provides its physical features to the biochemicals when associated together. These can easily describe the superior results in the reduction obtained in three fungal populations and soil microbial total counts compared with the conventional fertilization.

\subsection{Sunflower growth and productivity}

Data in fig. (6) indicate the effect of different biofertilization treatments on sunflower var. Giza 102 plant height $(\mathrm{cm})$, seed yield (ton/fed) and the oil yield (ton/fed) compared to the conventional chemical fertilization as the control treatment. Observations illustrated that under the dominancy of the biotic stress of soil borne diseases, the application of the biofertilizers was more appreciated to increase sunflower yield compared to the conventional chemical fertilization. The highest observations were obtained from EM-X followed by EM5 MEM1, then the conventional chemical fertilization as the control treatment, respectively. Also, for oil yield (ton/fed) the superior observations were obtained from EM-X, but with no significant differences between the other biofertilizers and compared to the conventional chemical fertilization as the control treatment. Similarly, plant growth promoting rhizobacteria (PGPR) has positive impacts on plant growth and productivity. It acts as phytostimulators and biofertilizers, thus enhances crop growth and yield through nutrient uptake and plant growth 
regulators. It also acts as biocontrol agents by production of antibiotics, triggering induced local or systemic resistance (Bouizgarne, 2013).

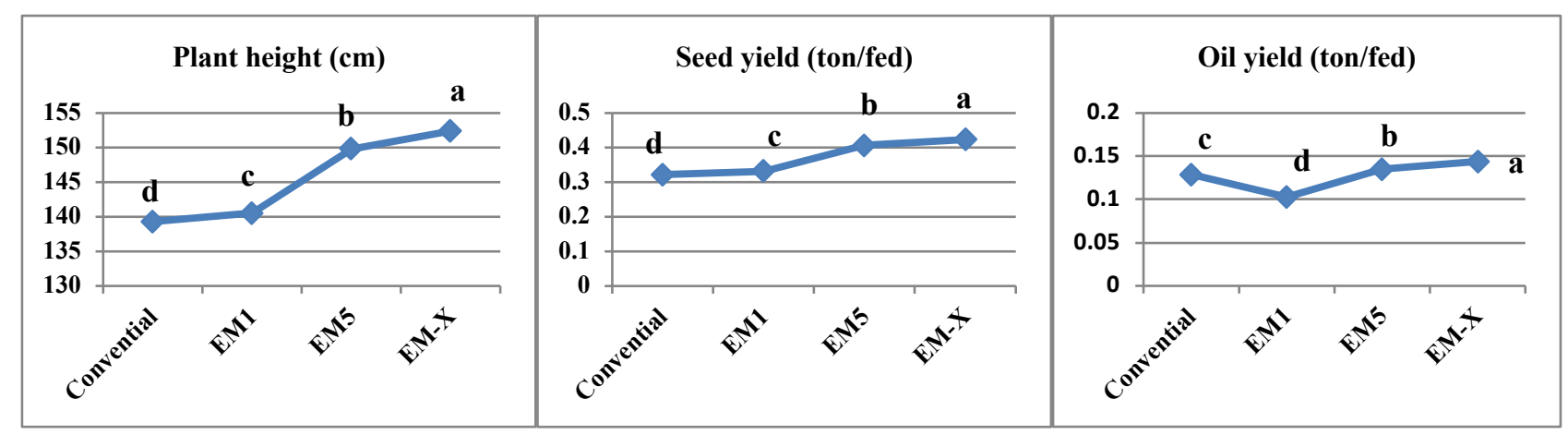

Fig. (6). Effect of different fertilization treatments on sunflower plant height $(\mathrm{cm})$ and yield (ton/fed) under Nubaria province conditions.

Means having similar letters at same column has no significant differences at $P \geq 0.05$

\section{Effect of the Interaction between Organic and Biofertilization Treatments on}

\subsection{Disease incidence}

Data represented in table (2) indicate that the most effective treatment on suppressing percentage of damping off or root-rot incidence was the interaction between organic amendments (rice straw+EM1+urea, biocha + compost, rice straw+EM1, bokashi, compost and cow manure, respectively) $\times$ biofertilizers (EM-X, EM5 and EM1, respectively) compared the treatment without organic amendments $\times$ conventional as the control treatment. Damping off disease was suppressed by the interaction treatments of rice straw $+\mathrm{EM} 1+$ urea or biochar+compost $\times \mathrm{EM}-\mathrm{X}$, followed by rice straw+EM1+urea or biochar+compost $\times$ EM5, then rice straw+EM1 $\times$ EM$\mathrm{X}$, respectively, at both pre and post emergence stages. Similarly, root-rot was highly suppressed by the same consequences; i.e. the interaction of rice straw+EM1+urea or biochar+compost $\times$ EM-X, followed by EM5, then EM1, respectively. The mode of action for the interaction between organic amendments and biofertilizer treatments, specifically rice straw+EM1+urea, in suppressing $M$. phasolinae, $S$. rolfsii and $R$. solani could be understood as follows; when soil amendments were added; the beneficial microorganisms such as EM1 can promote the soil conditions enriching the soil biota after adjusting the $\mathrm{C}$ : $\mathrm{N}$ ratio and $\mathrm{pH}$. Thus, induce the release of ammonia and ammonia related compounds in the rhizosphere to suppress the carpogonia germination of sclerotia of S. sclerotiorum (Hung-Chang et al., 2002). Meanwhile, application of urea to the soil was effective in preventing carpogenic germination of sclerotia of $S$. sclertiorum that were not in direct 
contact with the soil, as ammonia is a key toxic component for the suppression of this pathogen. Yet, chemical nitrogen fertilization shouldn't be applied in high concentration in a short time period particularly in an infested area, because it provides the preferable conditions for the soil borne diseases to produce its mass injury (Hung-Chang et al., 2002). Recently, it has been reported that soil with biochar and compost can trigger systemic plant defense and suppress the disease severity of soil borne pathogens (Akhter et al., 2015).

\subsection{Fungal pathogens and microbial population}

The observations in table (3) indicated that in 90 days after sowing dates, the interaction treatments between organic amendments and biofertilizers decreased significantly the populations of sunflower rhizoshpere associated fungal pathogens; i.e. M. phaseolina, S. rolfsii and $R$. solani as well as increased significantly the microbial total counts. The highest suppression of fungal pathogens was obtained by the interaction treatments of rice straw+EM1+urea $\times$ EM-X, followed by EM5, then EM1, this agrees with Sudha and Prabhu (2008). However, the highest increase of microbial total counts was obtained by the interaction treatments (biochar+compost $\times \mathrm{EM}-\mathrm{X}$ ), followed by EM5, then EM1, this agrees with Nielsen et al. (2018). This could be understood though what Higa (2000) told that, when the soil amendments was fermented with $\mathrm{EM}_{1}$ while incorporation into the soil particularly when enough soil moisture is available, it improves the soil conditions towards the dominancy of the beneficial microorganisms in the soil and vice versa for the pathogenic ones. The mode of action includes improving the soil physical and chemical properties and release of some bio-chemicals in the soil such as esters, organic acids, phenols and urea compounds. This increase the total count of the rhizosphere beneficial microorganisms and vice versa the decay microorganisms, thus enhance the plant growth and productivity (Toyoto and Kimara, 1991).

\subsection{Sunflower growth and yield}

Data presented in table (4) indicate that all the interactions among the different organic soil amendments and biofertilizer treatments increased significantly plant height $(\mathrm{cm})$, seed yield (ton/fed) and the oil yield (ton/fed) of sunflower grown at Nubaria province and infested with root-rot and damping off diseases during 2017 summer season when compared with the control treatment (without treatment $\times$ conventional). The highest observations were obtained from the interaction rice straw+EM1+urea $\times$ EM-X. This can be understood in the light of what reported by Higa (2000) and Sulok et al. (2018), who told that organic farming as an environmental friendly method of cultivation provides several benefits to the farmers, because it contains many plant nutrients (nitrogen, phosphorus, potassium and many other essential nutrients). It also increases infiltration of water and enhances retention of nutrients, reduces wind and water erosion and 


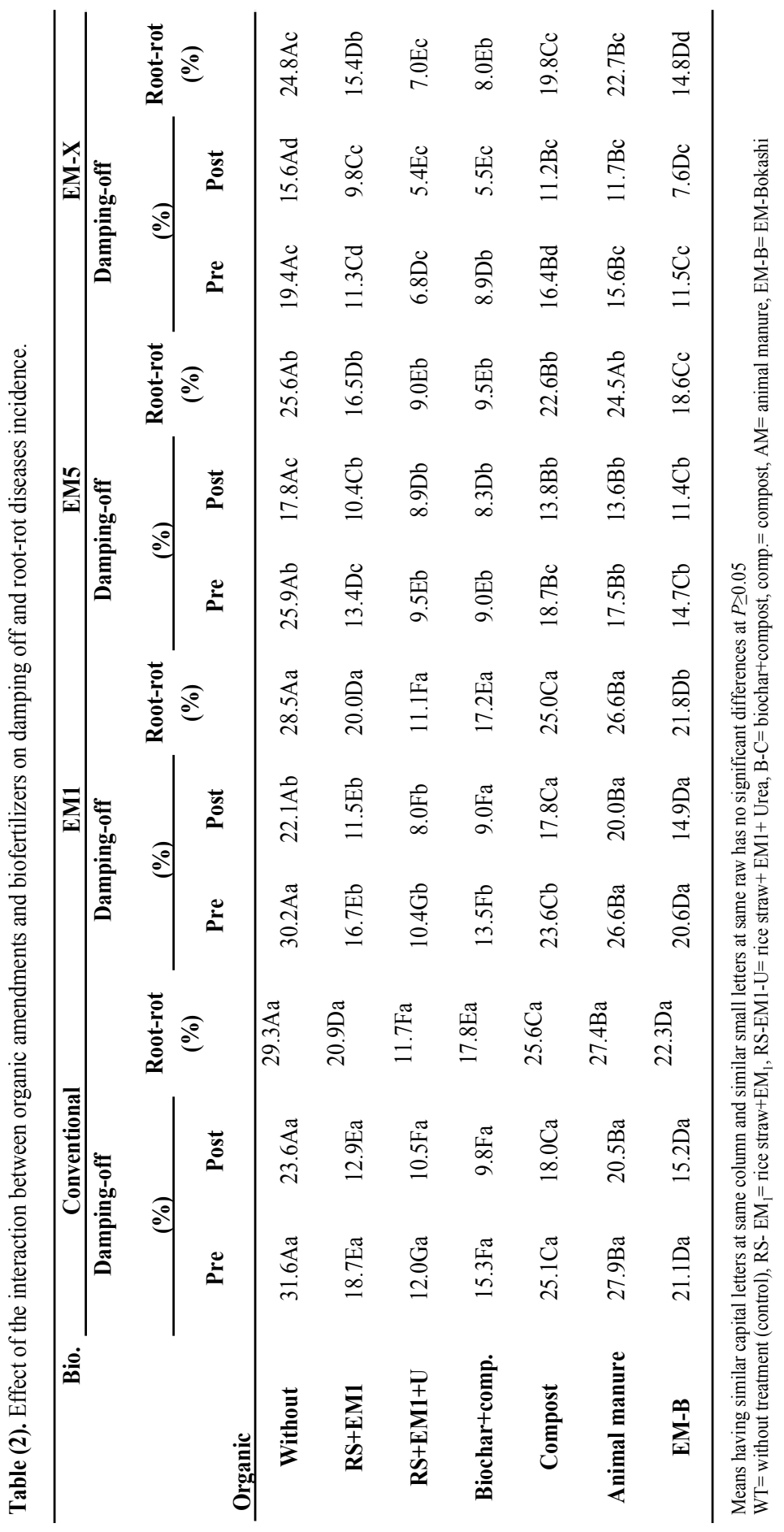

Egyptian J. Desert Res., 68, No. 2, 277-298 (2018) 


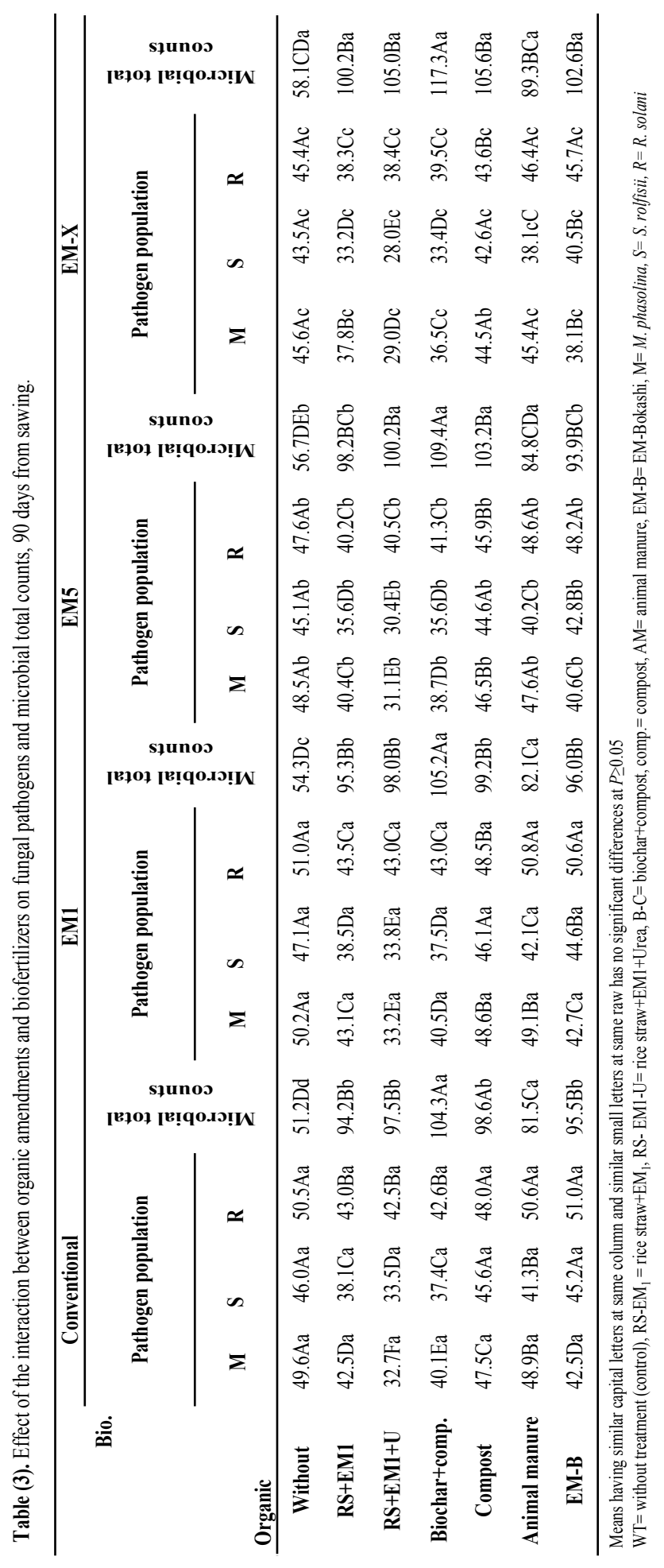

Egyptian J. Desert Res., 68, No. 2, 277-298 (2018) 


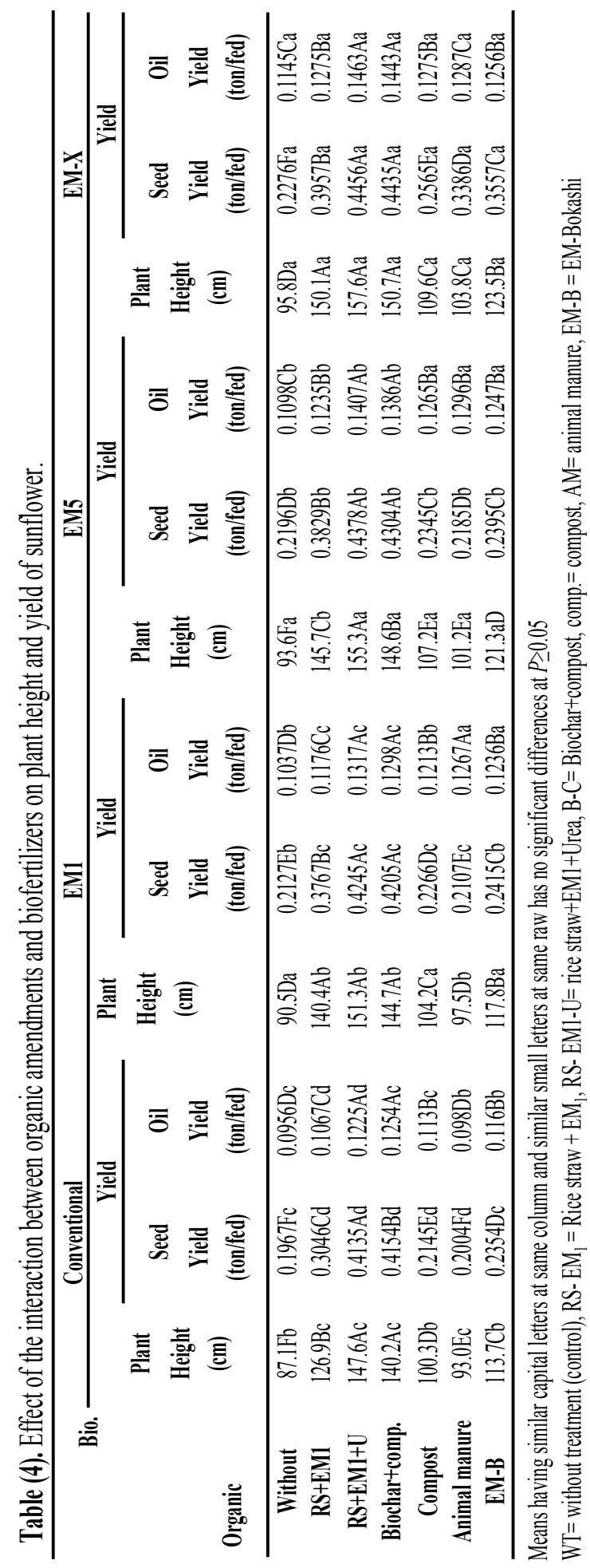

Egyptian J. Desert Res., 68, No. 2, 277-298 (2018) 
promotes growth of beneficial organisms that help plants to resist soil borne diseases. Moreover, it helps in $\mathrm{CO}_{2}$ restoration in soil and reduces of $\mathrm{CO}_{2}$ emissions into the atmosphere that produce global worming (Ross, 2008). The organic fertilization treatments such as EM-bokashi, biochar, compost and animal dung stimulated plant resistance to soil-borne diseases, therefore enhanced significantly plant growth, yield and its attributes and chemical composition (Abdel-Ati and El-Hadidy, 2013 and Salmani et al., 2014).

\section{CONCLUSION}

Biotic stress is the main challenge that face the universal agricultural production, yet, soil borne diseases will remain the most serious ones to challenge the plant growth and productivity. Likewise this study; soil borne pathogens were integrated together to challenge the sunflower growth and productivity under the desert conditions of Nubaria province, Egypt. Under these conditions, soil amendments will deliver issue to mitigate diseases bad consequences within several effective modes of actions. The integration between organic and biofertilizers as soil amendments will be the most effective ecofriendly strategy to management of sunflower diseases caused by soil borne pathogens overcome this dramatic condition to conserve the environment and produce an appreciated yield.

\section{REFERENCES}

A.O.A.C., Association of Official Analysis Chemists (1990). In: "Official Methods of Analysis". Published by the Association of Official Analysis Chemists, $15^{\text {th }}$ ed., Washington, D.C., U.S.A.

Abdel-Ati, A.A. and A.E.A. El-Hadidy (2015). Evaluation of sunflower productivity, root-rot and damping-off control by using some agricultural practices. Egyptian J. Desert Res., 65 (2): 257-279.

Abdel-Ati, A.A. and A.E.A. El-Hadidy (2017). Integration of EM-X biofertilization and sowing methods on encouragement of sunflower productivity and charcoal rot control under reclaimed soil conditions. J. Plant Prot. Path., Mansoura Univ., 8 (4): 155-164.

Abdel-Ati, A.A. and A.M.A. El-Hadidy (2013). Improving productivity and control of soil borne diseases of broad bean by using different fertilization. Egyptian J. Agron., 35 (2): 1-18.

Abd El-Hai, K.M., M.A. El-Metwaley, S.M. EL-Baz and A.M. Zeid (2009). The use of antioxidant and microelements for controlling dampingoff caused by Rhizoctonia solani and charcoal caused by Macrophomina phasolina on sunflower. Plant Path. J., 22 (2): 1-11.

Abd-El-Khair, H., K.H.E. Haggag and E.I. Elshahawy (2016). Soil application of Bacillus pumilus and Bacillus subtilis for suppression

Egyptian J. Desert Res., 68, No. 2, 277-298 (2018) 
of Macrophomina phaseolina and Rhizoctonia solani and yield enhancement in peanut. Int. J. Chem. Tech. Res., 9 (6): 142-152.

Akhter, A., K. Hage-Ahmed, G. Soja and S. Steinkellner (2015). Compost and biochar alter mycorrhization, tomato root exudation, and development of Fusarium oxysporum f. sp. lycopersici. Front Plant Science, 6: 529.

Barnett, H.L. and B.B. Hunter (1987). In "Illustrated Genera of Imperfect Fungi". $4^{\text {th }}$ Ed., McMillan Pub. Inc., USA.

Bhardwaj, D., M.W. Ansari, R.K. Sahoo and N. Tuteja (2014). Biofertilizers function as key player in sustainable agriculture by improving soil fertility, plant tolerance and crop productivity. Microbial Cell Factories, 13: 66-72.

Bonanomi G., V. Antignani, C. Manuela and F. Scala (2010). Identifying the characteristics of organic soil amendments that suppress soilborne plant diseases. Soil Biol. Biochem., 42: 136e144.

Bonanomi, G., F. Ippolito and F. Scala (2015). Biochar as a new soil amendment for controlling plant diseases: A "Black" future for plant pathology? J. Plant Pathol., 97 (2): 223-234.

Bouizgarne, B. (2013). Disease Management, In: Bacteria for Plant Growth Promotion and Disease Management Springer-Verlag Berlin Heidelberg, $367 \mathrm{pp}$.

Chapman, H.O. and P.E. Pratt (1978). Methods of analysis for soils, plants and water. Univ. of California Agric. Sci., Priced Publication 4034, p. 50 .

Cloud, G.L. and J.C. Rupe (1991). Comparison of three media for enumeration of sclerotia of Macrophomina phaseolina. Plant Dis., 75: 771-772.

Collins, C.P. and H. Lyne (1985). In "Microbiological Methods". $5^{\text {th }}$ Ed. Butter Worths, London, UK.

Deshmukh, M.A., R.M. Gade, Y.K. Belkar and M.D. Koche (2016). Efficacy of bioagents, biofertilizers and soil amendments to manage root rot in greengram. Legume Research, 39 (1): 140-144.

Duncan, D.B. (1955). Multiple range and multiple F-test. Biometrics, 11: 124.

Edwards, D., H. Kerp and H. Hass (1998). Stomata in early land plants: an anatomical and ecophysiological approach. J. Experim. Bot., 49: 255-278.

Figueiredo, M.V.B., A. Bonifacio, A.C. Rodrigues, F.F. de Araujo and N.P. Stamford (2016). Beneficial Microorganisms: Current Challenge to Increase Crop Performance. In: "Bioformulation: For Sustainable Agriculture" (Arora, N.K., S. Mehnaz and R. Balestrini eds.), Springer, New Delhi, p. 53-70.

Gilman, J.C. (1971). In "A Manual of Soil Fungi". $2^{\text {nd }}$ Ed. Iowa State College Press, Ames, Iowa, 450 pp. 
Higa, T. (1991). Effective Microorganisms: A biotechnology for Mankind. Parr, J.F., S.B. Hornick and C.E. Whitman (eds.). Proceedings of the First International Conference on Kyusei Nature Farming. U.S. Department of Agriculture, Washington, D.C., USA, p. 8-14.

Higa, T. (2000). An Agricultural Revolution with EM Technology. In: "Our Future Reborn". Sunmark Publishing Inc., Japan, 81 pp.

Hung-Chang, H., R. Scott Erickson, C. Chang, J.R. Moyer, F.J. Larney and J.W. Huang (2002). Organic soil amendments for control of apothecial production of Sclerotinia sclerotiorum. Plant Path. Bull., 11: 207-214.

Kausar, H., M.R. Ismail, H.M. Saud, Z. Berahim, S.H. Habib, R. Othman, S.H. Bhuiyan (2016). Microbial Composting of Rice Straw for Improved Stability and Bioefficacy. In: "Plant, Soil and Microbes" p. 271-290.

Ko, W. and F.K. Hora (1971). A selective medium for quantitative determination of Rhizoctonia solani in soil. Phytopathology, 61: 707-710.

Lingappa, Y. and J.L. Lockwood (1962). Chitin media for selective isolation and culture of actinomycetes. Phytopathology, 52: 317- 325.

Mehta, C.M., U. Palni, I.H. Franke-Whittle and A.K. Sharma (2014). Compost: Its role, mechanism and impact on reducing soil-borne plant diseases. Waste Management, 34 (3): 607-622.

Morsy, S.M. and A.E. El-Korany (2007). Suppression of damping-off and charcoal-Rot of sunflower with composted and non-composted agricultural wastes. Egyptian J. Phytopathol., 35 (2): 23-38.

Nielsen, S., S. Joseph, J. Ye, C. Chia, P. Munroe, L. van Zwieten and T. Thomas (2018). Crop-season and residual effects of sequentially applied mineral enhanced biochar and $\mathrm{N}$ fertilizer on crop yield, soil chemistry and microbial communities. Agriculture, Ecosystems and Environment, 255: 52-61.

Reddy, P.P. (2016). Compost in Disease Management. In: "Sustainable Crop Protection under Protected Cultivation". Springer-Verlag, Berlin, Heidelberg, Germany, p. 72-81.

Ross, H.M. (2008). Managing livestock manure. Published by the Alberta Agriculture and Rural Development, Alberta. Available online at: http//www1.agric.gov.ab.ca/ \$department/ deptdocs. nsf

Russell, D.F. (1991). MSTATC, Directory Crop Soil Science Dept., Michigan Univ., USA.

Salmani, M.S., F. Khorsandi, J. Yaserbi and N. Karimian (2014). Effect of biochar on sunflower yield and some soil properties in a copper contaminated calcareous soil. Adv. Env. Bio., 8 (87): 2310-2213.

Sharma, M.P., S.K., R.D. Sharma, K.K.P. Prasad and R. Dey (2014). Application of Arbuscular Mycorrhizal Fungi in Production of Annual Oilseed Crops. (Solaiman, Z.M. et al. eds.). In: "Mycorrhizal

Egyptian J. Desert Res., 68, No. 2, 277-298 (2018) 
Fungi: Use in Sustainable Agriculture and Land Restoration”. Soil Biology 41, Springer-Verlag, Berlin, Heidelberg, Germany.

Shin, K., G. Diepen, W. Blok and H.C. Ariena (2017). Variability of effective micro-organisms (EM) in bokashi and soil and effects on soil-borne plant pathogens. Crop Protection, 99: 168-176.

Steadman, J.R., J. Marcinkowska and S. Rutledge (1994). A semi-selective medium for isolation of Sclerotium rolfsii. Can. J. Plant Pathol., 16: 68-70.

Sudha, A. and S. Prabhu (2008). Evaluation of organic soil amendments against Macrophomina Phaseolina (Tassi). Journal of Biopestcides, 1 (2):143-145.

Sulok, K.M.T., O.H. Ahmed, C.Y. Khew and J.A.M. Zehnder (2018). Introducing natural farming in black pepper (Piper nigrum L.) cultivation. International Journal of Agronomy, Article ID 9312537, $6 \mathrm{pp}$.

Tokeshi, H., M.C. Alves, A.B. Sanches and D.Y. Harada (1998). Effective microorganisms for controlling the phytopathogenic fungus Sclerotinia sclerotiorum in lettuce. In: Parr, J.F. and S.B. Hornick (eds.). Proceedings of $4^{\text {th }}$ International Conference on Kysei Nature Farming, Paris, France, p. 131-139, 19-21 June 1995 U.S.A.

Toyoto, K. and M. Kimara (1991). Antagonists against Fusarium oxysporum f. sp. raphani in soil. Japanese Journal of Soil Science. Plant and Nutrition, 62: 21-26.

Weiss, E.A. (2000). Oil seed crops Blackwell Sci Led. London, 364 pp. 


\section{تأثير إضافات التربة الحيوية والعضوية على أمراض موت البادرات وأعفان الجذور لاوار الثمس تحت ظروف الأراضي المستصلحة}

$$
\text { قسم وقاية النباتي، مركز أحمد الحديديث الصحوث الصحر اء، المطرية، القاهرة، مصر }
$$

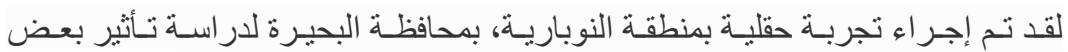

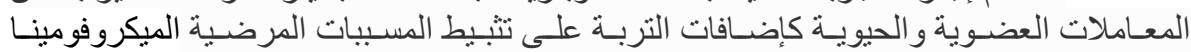

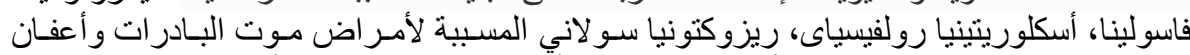

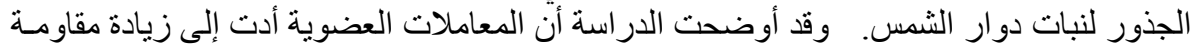

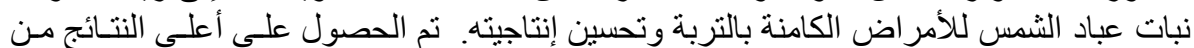

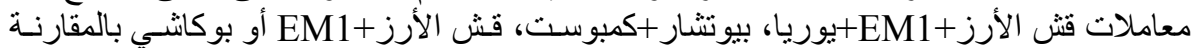

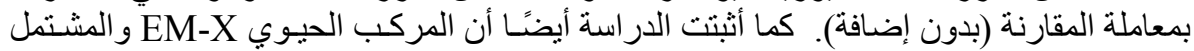

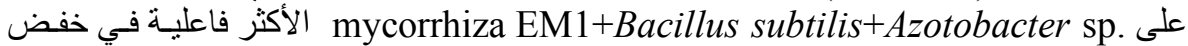

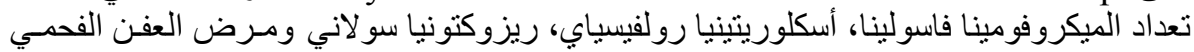

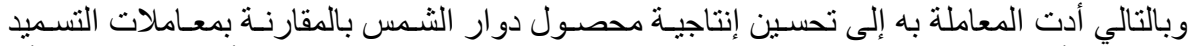

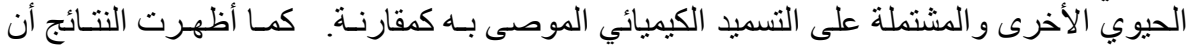

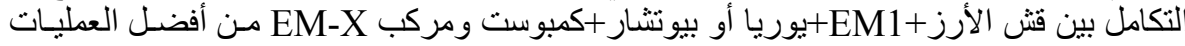

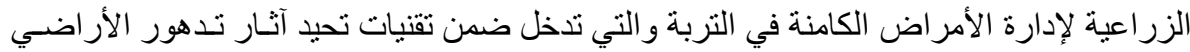

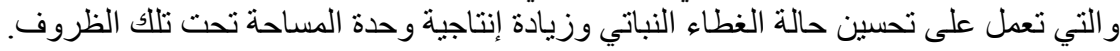

